\title{
Peripheral Odontogenic Fibroma: A Rare Case Report
}

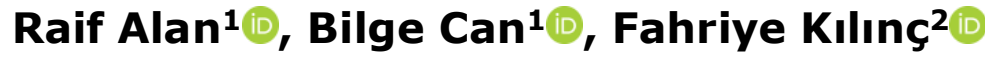 \\ ${ }^{1}$ Necmettin Erbakan University, Faculty of Dentistry, Department of Periodontology, Konya, Turkey \\ 2 Necmettin Erbakan University, Faculty of Medicine, Department of Pathology, Konya, Turkey
}

\section{Correspondence:}

\section{Dr. Raif ALAN}

Necmettin Erbakan University, Faculty

of Dentistry, Department of

Periodontology, Konya, Turkey.

E-mail: drraifalan17@gmail.com

Received: 31 January 2018

Accepted: 16 March 2018

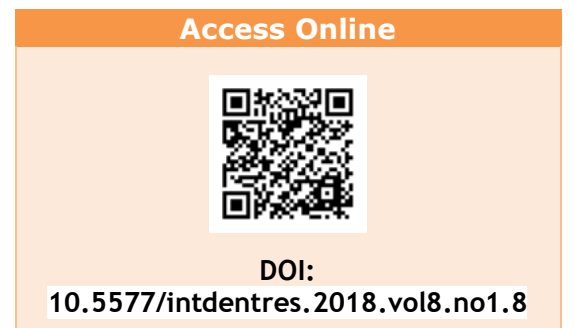

\section{Introduction}

The odontogenic fibroma has been described by the World Health Organization as "a rare neoplasm characterized by varying amounts of inactive-looking odontogenic epithelium embedded in a mature, fibrous stroma". There are two types that are differentiated based on localization, including the intraosseous or central type, and the extraosseous or peripheral type

\begin{abstract}
To present the clinical presence, histopathological features, and management of a rare peripheral odontogenic fibroma (POF) case. A 32-year-old male patient was referred to the clinic complaining of a localized gingival enlargement of the anterior maxillary region. Initial periodontal treatment was delivered and the patient was informed about proper oral hygiene. After the initial periodontal treatment, the lesion was surgically excised while preserving the marginal line. POF was diagnosed based on clinical and histopathological findings. Normal mechanical oral hygiene was established in the postoperative period. No recurrence was observed during this follow-up period, and the patient was included in the maintenance phase. POF was treated with local excision and the prognosis was excellent. Regular follow-ups are very important for such patients after surgery.
\end{abstract}

Keywords: Gingival lesion, localized gingival enlargement, odontogenic tumors, peripheral odontogenic fibroma

How to cite this article: Alan R, Can B, Kılınç F. Peripheral Odontogenic Fibroma: A Rare Case Report. Int Dent Res 2018;8(1):45-49.
(1). Peripheral odontogenic fibroma (POF) is the counterpart of the central odontogenic fibroma in the mucosa (2). POF occurs within a broad age range, with peak incidence in the second to fourth decades of life (3-5). The recurrence rate of POF, observed mostly in the incisor tooth area, is extremely variable. Some studies have reported a low recurrence rate of POF $(4$, $6,7)$ while others have reported a recurrence rate between $38.9 \%$ (8) and 50\% (3). 
Clinically, POF usually presents as an asymptomatic, firm, nonulcerated, well-circumscribed swelling similar in color to the surrounding soft tissue, and exhibiting pedunculated or sessile mass properties (9). Conservative local excision is the preferred treatment method $(4,6,10)$.

Due to its rarity, limited information is available about POF, with the majority of data obtained from case reports and small case series (3). This report aims to present the clinical presence, histopathological features, and management of a rare POF case.

\section{Case Report}

A 32-year-old male patient presented at the clinic complaining of a localized gingival enlargement of the anterior maxillary region. Anamnesis results indicated that the patient was systemically healthy and a non-smoker.

The patient stated that the growth recurred despite surgical removal five times. Clinical examination revealed a soft tissue lesion between the right central and lateral incisor teeth, affecting the gingival margin. The lesion was tender, firm, nonulcerated, and approximately $10 \times 12 \times 7 \mathrm{~mm}$ in size (Fig. 1A). Teeth in the relevant region had no periodontal pockets, and the radiographic examination showed no pathology (Fig. 1B).

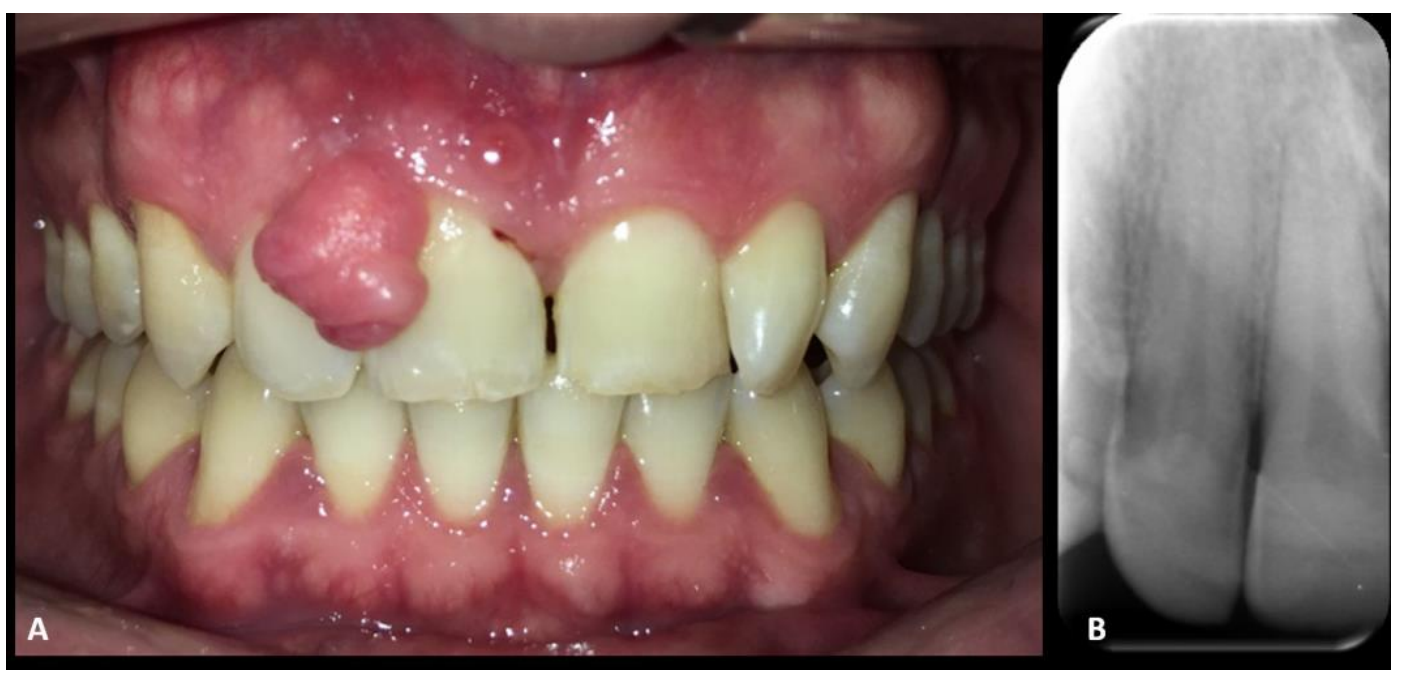

Figure 1. A. Preoperative intraoral view of the lesion. B. Preoperative periapical radiography of the relevant region.

Since the patient presented with poor oral hygiene, initial periodontal treatment was applied and the patient was informed about performing adequate oral hygiene. On the day of surgery, following local anesthesia, an excisional biopsy of the lesion was performed by gingivectomy with preservation of the marginal line. The lesion material was stored in $10 \%$ formalin for routine hematoxylin and eosin staining. Gingivoplasty was performed to create a symmetrical postoperative gingival tissue contour. The flap was removed for bone evaluation after gingival contouring (Fig. 2). The area of the lesion was cleaned, sutured (Fig. 3), and covered with a periodontal dressing to protect the surgical site. After the procedure, the patient was prescribed with analgesics as needed and chlorhexidine mouthwash and informed about postoperative care. The postoperative course of the patient was uneventful.

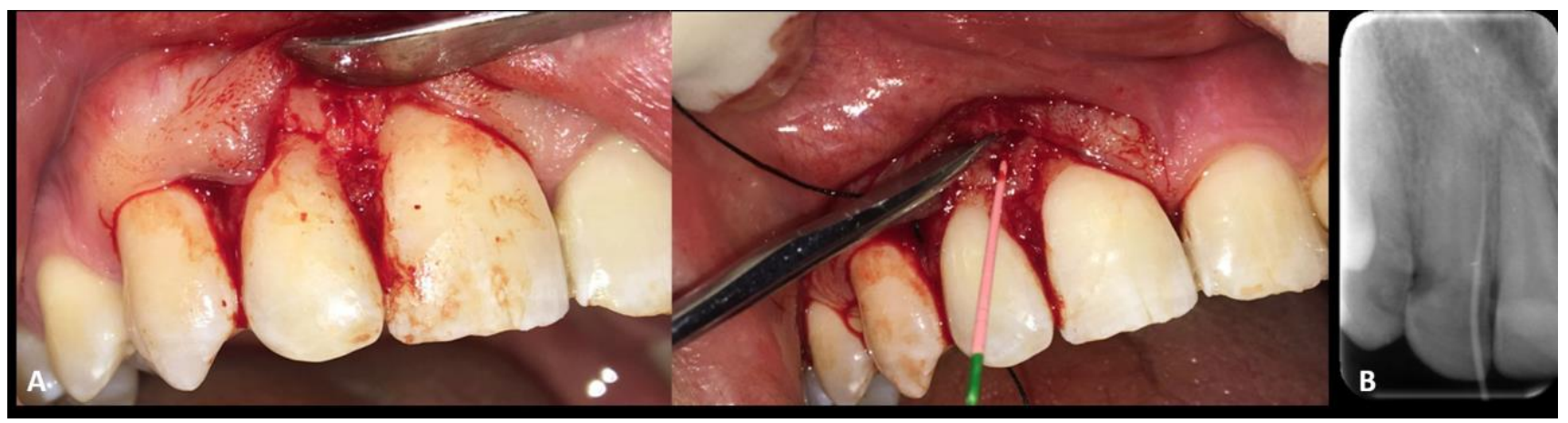

Figure 2. A. Flap elevation after excisional biopsy of the lesion. B. Periapical radiography of the relevant region during surgery. 


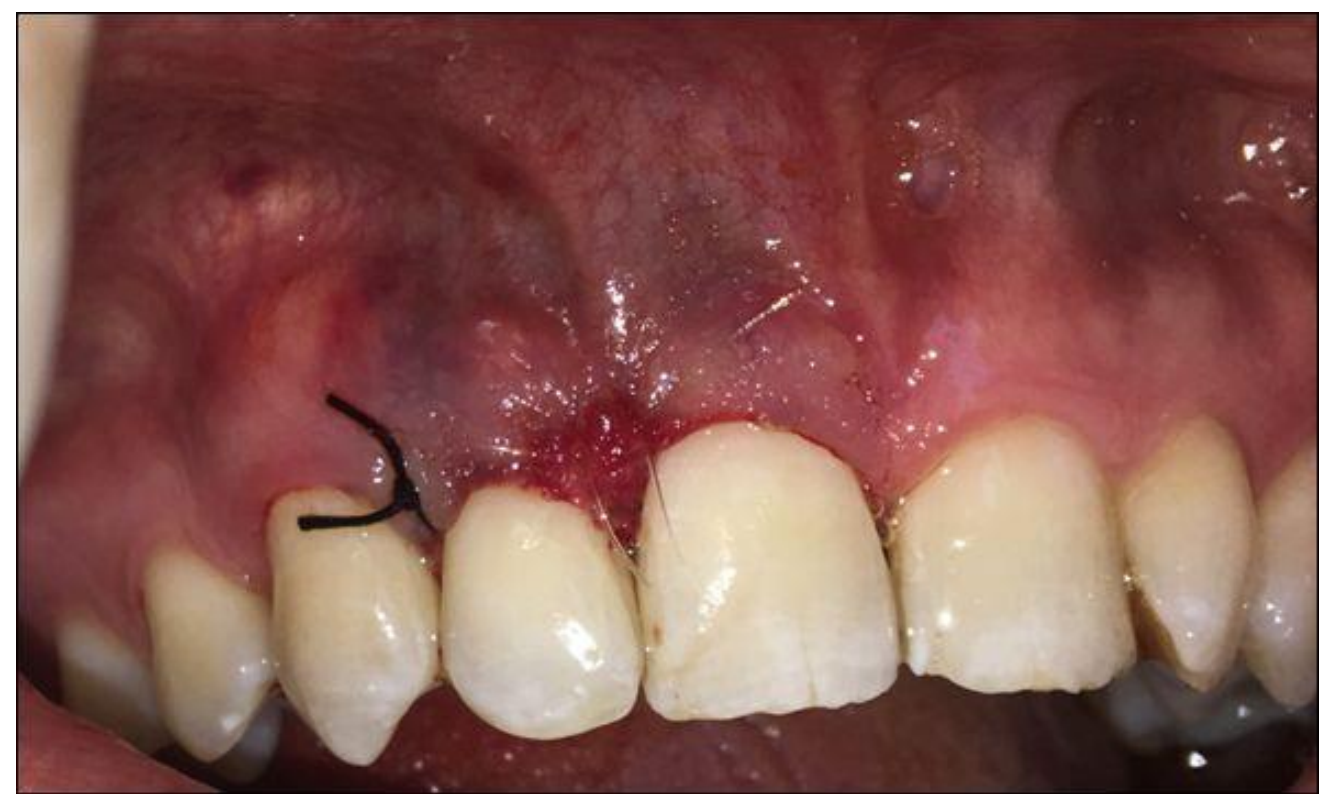

Figure 3. Suture placement.

The periodontal dressing and sutures were removed after one week. The patient was asked to brush his teeth gently with a soft toothbrush and rinse with chlorhexidine mouthwash. In the postoperative period, adequate mechanical oral hygiene was established.
The patient was monitored at four weeks, three months, and six months for recurrence. No recurrence was observed during the follow-up period (Fig. 4), and the patient was included in the maintenance phase.

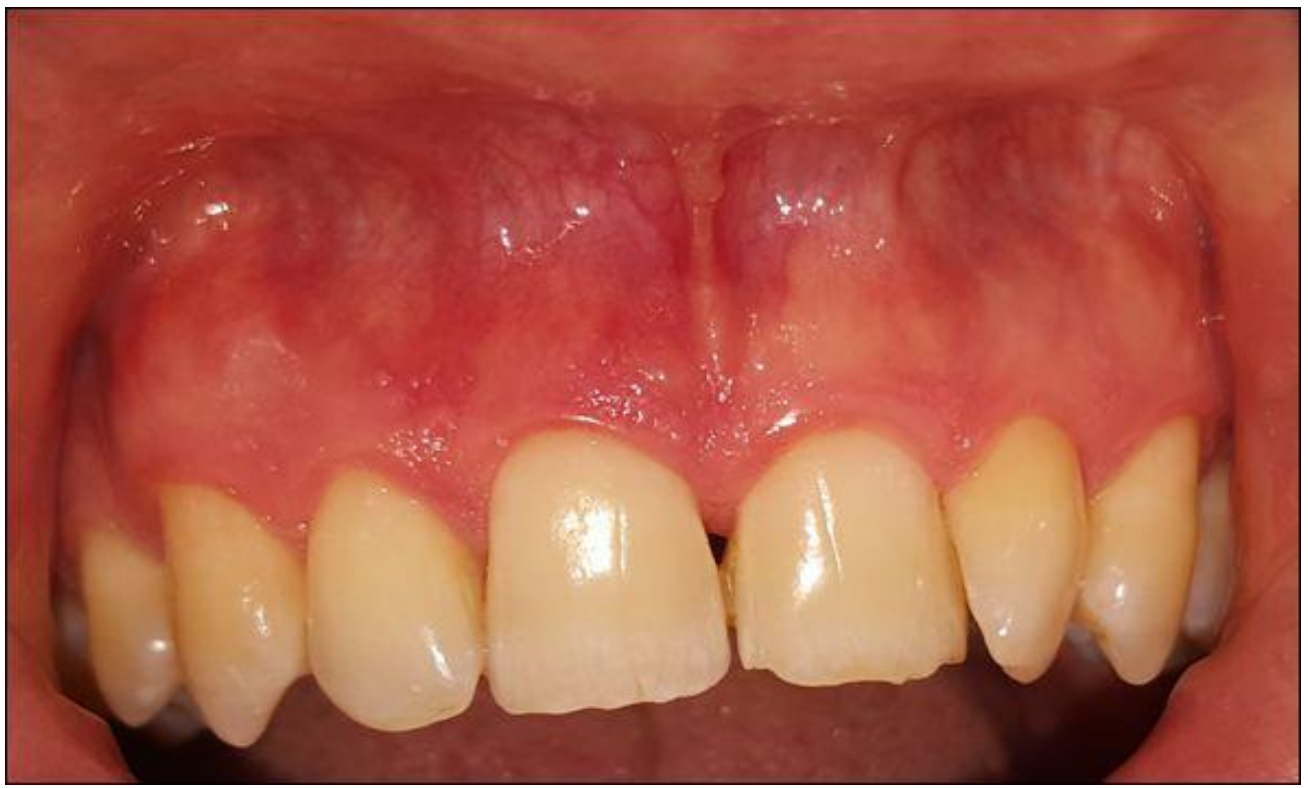

Figure 4. Postoperative intraoral view of the lesion at $6^{\text {th }}$ month.

\section{Histopathological examination}

Hematoxylin / Eosin sections showed a nodular lesion covered with hyperplastic stratified squamous epithelium.
Several small areas of odontogenic epithelium islets and calcification foci were observed in the fibrous stroma, which containing collagenous bundles and chronic inflammatory cells (Fig. 5) 


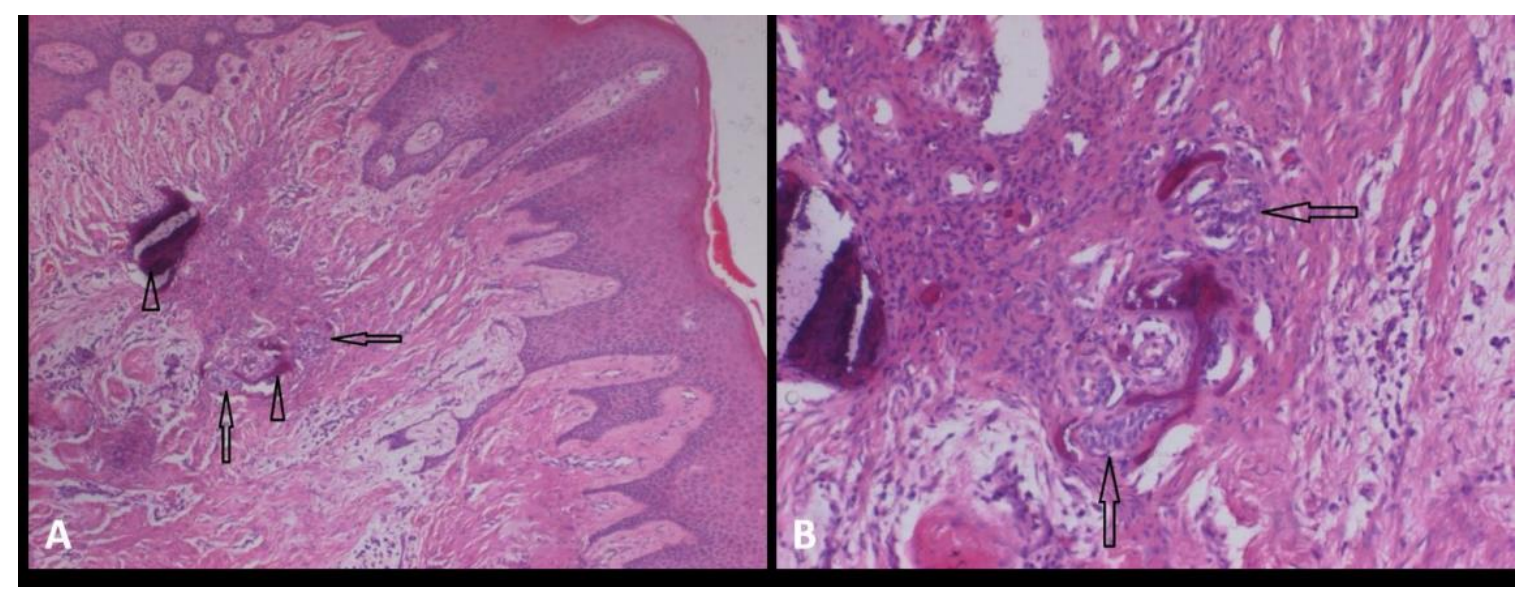

Figure 5: A. Odontogenic epithelial islets (arrows) and calcified foci (arrowheads) in the fibrocollagenous stroma under hyperplastic squamous epithelium (Hematoxylin / Eosin, original magnification x40). B. Odontogenic epithelial islets (arrows) (Hematoxylin / Eosin, original magnification $x 100$ ).

\section{Discussion}

An odontogenic fibroma is a benign odontogenic tumor that can occur centrally or peripherally (4). POF is usually manifested clinically as a focal swelling (9-12). Studies on POF are controversial, and no clear opinion has been established on age, gender, and race (13).

The histogenesis of POF is not fully understood. Some studies have pointed to the periodontal ligament $(\mathrm{PL})$ as the origin of the fibroblastic component, based on the formation of these lesions in the dentulous regions $(6,14)$. On the other hand, Ritwik and Brannon (3) identified two cases arising from edentulous crests and claimed that the PL was not a possible source. The origin sites for the epithelial component include the basal layer of the upper mucosa (6) or dental lamina residues $(3,5,6)$. However, local irritants such as inadequate restorations, presence of plaque and calculus, and excessive chewing forces are possible etiologic factors for POF (10).

POF is often misdiagnosed as a pyogenic granuloma (15-17). Pyogenic granuloma (PG) is a flat or lobular mass, usually having an ulcerated surface, and a color varying from pink to purple (18). The clinical features of PG are quite similar to POF, making it difficult to distinguish one from the other. POF may be difficult to differentiate from other extensive fibrous gingival lesions (19). It has been proposed that $\mathrm{POF}$, the most common peripheral odontogenic tumor, be included in the differential diagnosis of gingival lesions (17).

Since POF is a rare gingival lesion there is a general lack of information on its characteristics. In particular, the likelihood of recurrence is unclear as follow-up studies are limited (20). POF is treated with local excision and the prognosis is excellent (12). Ritwik and Brannon (3) stated that recurrence of the lesion is correlated with insufficient surgical excision. The authors indicated that in the majority of histopathological slides they could not distinguish between lesional and normal connective tissue, making it difficult to determine whether a whole excision was performed adequately. The authors found that neither the size of the lesion nor the patient's race were associated with POF recurrence.

\section{Conclusions}

In conclusion, a POF lesion may show a clinically significant recurrence rate despite its rarity. To determine the appropriate treatment choice for the patient, pathologists and clinicians should act together (21). Regular postoperative follow-up and maintenance are very important for patients after surgery.

Informed Consent: Written informed consent was obtained from the patient who participated in this study.

Peer-review: Externally peer-reviewed.

Author Contributions: Conception - R.A.; Design - B.C.; Supervision R.A.; Materials - B.C.; Data Collection and/or Processing - F.K.; Analysis and/or Interpretation - B.C., F.K.; Literature Review - R.A., B.C.; Writer - R.A.; Critical Review - F.K.

Conflict of Interest: No conflict of interest was declared by the authors.

Financial Disclosure: The authors declared that this study has received no financial support. 


\section{References}

1. Philipsen HP, Reichart PA, Sciubba JJ, van der Waal I. Odontogenic fibroma. In: Barnes L, Eveson JW, Reichart P, Sidransky D, editors. World Health Organization Classification of Tumours. Pathology and Genetics of Head and and Neck Tumours. Lyon: IARC Press; 2005.315.

2. de Matos FR, de Moraes M, Neto AC, Miguel MC, da Silveira EJ (2011) Central odontogenic fibroma. Ann Diagn Pathol 15(6): 481-4. [Crossref]

3. Ritwik P, Brannon RB. Peripheral odontogenic fibroma: a clinicopathologic study of 151 cases and review of the literature with special emphasis on recurrence. Oral Surg Oral Med Oral Pathol Oral Radiol Endod 2010;110:357-63. [Crossref]

4. Eversole LR. Odontogenic fibroma, including amyloid and ossifying variants. Head Neck Pathol 2011;5:335-43.

5. Garcia BG, Johann AC, da Silveira-Junior JB, Aguiar MC, Mesquita RA. Retrospective analysis of peripheral odontogenic fibroma (WHO-type) in Brazilians. Minerva Stomatol 2007;56:115-9. [Crossref]

6. Slabbert HV, Altini M. Peripheral odontogenic fibroma: a clinicopathologic study. Oral Surg Oral Med Oral Pathol 1991;72:86-90. [Crossref]

7. Kenney JN, Kaugars GE, Abbey LM. Comparison between the peripheral ossifying fibroma and peripheral odontogenic fibroma. J Oral Maxillofac Surg 1989;47:378-82. [Crossref]

8. Daley TD, Wysocki GP. Peripheral odontogenic fibroma. Oral Surg Oral Med Oral Pathol 1994;78:329-36.

9. Sciubba J, Fantasia J, Kahn LB, editors. Atlas of tumour and pathology. Washington DC: Armed forces Institute of Pathology 2001. p. 105-26. [Crossref]

10. Patel S, Vakkas J, Mandel L. Recurrent peripheral odontogenic fibroma. N Y State Dent J 2011;77:35-7.

11. Rinaggio J, Cleveland D, Koshy R, Gallante A, Mirani N. Peripheral granular cell odontogenic fibroma. Oral Surg Oral Med Oral Pathol Oral Radiol Endod 2007;104:676-9. [Crossref]

12. Baiju CS, Rohatgi S. Peripheral odontogenic fibroma: a case report and review. J Indian Soc Periodontol 2011;15:273-5. [Crossref]

13. Bosco AF, Bonfante S, Luize DS, Bosco JM, Garcia VG. Periodontal plastic surgery associated with treatment for the removal of gingival overgrowth. J Periodontol 2006;77(5):9228. [Crossref]

14. Marx RE, Stern D. Oral and maxillofacial pathology: a rationale for diagnosis and treatment. Chicago: Quintessence, 2003. p. 674-5. [Crossref]

15. Lin CT, Chuang FH, Chen JH, Chen MC, Chen YK. Peripheral odontogenic fibroma in a Taiwan Chinese population: a retrospective analysis. Kaohsiung J Med Sci 2008;24:415-21.

16. Siar $\mathrm{CH}, \mathrm{Ng} \mathrm{KH}$. Clinicopathological study of peripheral odontogenic fibromas (WHO-type) in Malaysians (1967-95). Br J Oral Maxillofac Surg 2000;38:19-22. [Crossref]

17. Manor $\mathrm{Y}$, Mardinger $\mathrm{O}$, Katz J, et al. Peripheral odontogenic tumours-differential diagnosis in gingival lesions. Int $\mathrm{J}$ Oral Maxillofac Surg 2004;33:268-73. [Crossref]

18. Neville BW, Damm DD, Allen CM, et al. Oral and Maxillofacial Pathology, 3rd edition. St. Louis: Saunders Elsevier, 2009.50770. [Crossref]

19. Neville BW, Damm DD, Allen CM, et al. Oral and Maxillofacial Pathology, 3rd edition. St. Louis: Saunders Elsevier, 2009:678 740.

20. Curran AE. Peripheral odontogenic tumors. Oral Maxillofac Surg Clin North Am 2004;16:399-408.

21. Silva CA, Passador-Santos F, Moraes Pde C, Soares AB, de Araújo VC. Peripheral odontogenic fibroma: an uncommonly overviewed lesion. J Craniofac Surg 2013;24:e216-9. [Crossref] 